\title{
obituary
}

\section{Alexander Wetmore}

Alexander Wetmore, who died in Maryland on 7 December 1978 at the age of 92 , was for over 50 years one of the leading figures in world ornithology. Born in Wisconsin on 18 June 1886, he lived all his life in the United States, devoting his professional life to two organisations, first the Biological Survey of the Department of Agriculture (1910-1924) and from 1924 the Smithsonian Institution. From 1945 to 1952 he served as Secretary of the Smithsonian Institution, and he continued to work there after his retirement until a short time before his death.

A good many living and recent ornithologists have had new subspecies, and even the occasional new species of bird named after them; but few have had the distinction of giving their name to a new genus, such as Wetmorethraupis, a new tanager of uncertain affinities discovered in northern Peru in 1963 and named by Lowery \& O'Neill in Wetmore's honour 'in recognition of his many outstanding contributions to ornithology, ranging from the classification and systematics of both recent and fossil birds to such diverse facets of the subject as bird migration and pterylosis.' Indeed Wetmore's name has become a household word among ornithologists, for his classification of the birds of the world, forming the basis for the well known 'Wetmore order', has, with modifications necessitated by new knowledge, become the generally accepted arrangement, as adopted in Peters' Checklist of Birds of the World and other authoritative compilations.

Dr Wetmore's eminence as a research ornithologist was based on an extraordinary capacity for work, meticulous accuracy, and a very wide range of interests. When he was Secretary of the Smithsonian he customarily arrived at his laboratory at about 6 a.m. and worked steadily on his scientific projects for three or four hours before devoting a full day's work to his duties as Secretary. Up to his late $80 \mathrm{~s}$ he continued to make regular field trips to Panama, collecting specimens and gathering information for his 4-volume Birds of the Republic of Panama, the last volume of which was left unfinished at his death. These qualities, applied to avian palaeontology at a time when the subject was in a state of comparative neglect, quickly made him a leading authority, his con- tributions providing almost all that was known of the birds from the extensive Oligocene deposits of western North America. Since 1914 he described as new 189 species and subspecies of birds, a record that must be unequalled in the 20th century.

Dr Wetmore was, in a sense, an oldfashioned ornithologist, museum-based, his field work centred round collecting -one who provides the facts that others use. He did not originate new theories, seeming distrustful of the sweeping generalisation, as is often the case with those who are very familiar with the facts and see, more clearly than most, the exceptions and difficulties that need to be taken into account. Advanced though it is in the accumulation of basic facts, ornithology still needs workers of his type; they provide the infrastructure that supports the more exciting new developments.

Alexander Wetmore was a tall man of quietly distinguished presence and great natural modesty, who treated the youngest aspiring ornithologist and the older established with equal courtesy. I never heard any of his American colleagues or friends speak of him other than with respect and affection. $\mathrm{He}$ will be remembered by the many British ornithologists who met him at the International Ornithological Congress at Oxford in 1966, still in full vigour and only regretting that he was becoming less efficient in the field as his hearing was beginning to fail.

D. W. Snow

\section{Sidnie Manton}

Dr Sidnie Manton, FLS, FRS (Mrs J. P. Harding), died peacefully in hospital on 2 January 1979 aged 76 . To students of zoology at the end of the last war she was already a legend.

In her first 20 years of professional life she had jointly opened the era of functional morphology with Graham Cannon in their paper on the feeding mechanism of Hemimysis; journeyed to Tasmania to study the endemic Anaspides; joined the expedition to the Great Barrier Reef and published on black corals; published on the embryology of Nebalia; sought-out Peripatus in Africa, and published on their feeding, digestion, excretion, sperm trans- fer, embryology and life-history. A graduate and fellow of Girton, she became college director of studies in natural science, university demonstrator in comparative anatomy and later joined the staff at King's College, London. Her Manual of Practical Vertebrate Morphology (1930, with J. T. Saunders) was, and still is (4th edition, 1969, with M. E. Varley) the most respected and reliable guide to vertebrate dissection.

Her election to the Royal Society in 1948 crowned a distinguished career and came as no surprise. No one could have guessed that she was poised to make an even more important contribution to scholarship in the next 25 years. A gap in publication from 1938 to 1945 represents the period her young family and a heavy teaching load at Kings, Birkbeck, Queen Mary and University Colleges were making big demands on her time, but it was then she conceived and began one of the most exciting and ambitious research projects in the history of zoology. The first part of this already classic series on the evolution of arthropod locomotory mechanisms was published in the Journal of the Linnean Society (Zoology) in 1950 and the final part (11) appeared in 1973. The series covered 1,000 pages and included almost as many superbly executed drawings gathered into 250 compound textfigures. Functional explanations were given of many arthropod characters previously regarded as curious indications of ancestry.

She was continually in demand here and abroad, to talk about her work. At one Linnean meeting she brought along working models of arthropod legs she had made to help her own understanding; that of the spider was as tall as she, and incorporated the arcuate sclerite, a marvellous engineering device to provide the acute flexure of the femur-patella joint. The nicest device she discovered was surely the rock of the arthropod coxae, lining-up the dorsal hinge joints to translate the depression of proximal podomeres into effective extension of the legs. She was awarded the Linnean Gold Medal in 1963 before half the series was completed.

The locomotion work was certainly conceived and executed in the grand manner, but it was merely a part of 
the greater scheme conceived much earlier, aimed at an understanding of arthropod phylogeny. She had extended and completed a draft of the late $O$. W. Tiegs on The Evolution of the Arthropoda and had discovered that much basic information was just not available. In 1960 she retired from her Readership at Kings and from then on enjoyed the hospitality of the British Museum (Natural History) as Honorary Research Associate and was also a Research Fellow of Queen Mary College. Freed from teaching she felt able to seek the information for herself, beginning with a major examination of the structure and function of the mandible which was published in a wonderfully illustrated paper of over 200 pages between parts 7 and 8 of the locomotion series. She was becoming increasingly impressed by the mutual exclusiveness of the engineering designs between and even within classes. She considered these designs to have evolved in response to different habits which persisted for long periods and that each lineage represented an independent attainment of the arthropod grade of organisation.

About this time she was cruelly afflicted by an arthritic condition, yet she had enjoyed lunch-time tennis on the BM court until she was well over 60. At the Myriapod Congress in Manchester in 1972 she was relatively mobile because of an ingenious mechanical aid for one leg designed and constructed by herself and husband. Looking down a microscope at an exhibit, she drew for me an accurate picture of the cataract which limited her field to a narrow jagged annulus. Cataracts were removed one by one and hip and wrist joints were extensively re-modelled. During this difficult period she wrote The Arthropoda, recently published by Oxford University Press, a masterly summary of her 50 years research into their habits, functional morphology and evolution, running to 527 pages and lavishly illustrated by 186 text figures. She corrected the proofs in hospital after one of her operations. During the last two years she had compiled four chapters of a new general text on arthropods, written and presented a paper to a symposium on the evolution of the major arthropod groups at Hull, contributed a review to a book on arthropod phylogeny and undergone a second pelvic joint operation. The strain was too great.

The arthropods were not the only animals in her life. Her home and garden housed a veritable menagerie of birds and mammals which she cared for each day. Over a period of 21 years she developed the long haired Colourpoint cats with such delightful tem- peraments and exported kittens to all points of the globe. The history of her Mingchiu cats is recounted in her book Colourpoint, Longhair and Himalayan Cats (1971). This work ran parallel to her arthropod studies and brought her world-wide acclaim from an entirely different public. All this while at the centre of a delightful household, cooking superb meals, a delightful person with a lively conversation and an understanding smile. She will be sorely missed by her husband, Dr J. P. Harding and her two children, Elizabeth and Martyn.

J. Gordon Blower

\section{E. R. Creed}

Edwin Robert Creed died on 28 November 1978, aged 42, after an illness of three months. His parents were both physiologists, his father being a Fellow of New College, Oxford, also of Winchester. Robert was among that group of boys from Marlborough School who, from the 1920s onwards, became distinguished as biologists.

Like his father, he went to Trinity College, Oxford. After graduating in zoology he remained in the department to carry out research in ecological genetics. It gained for him the PhD Degree, also a Research Fellowship at New College. When this expired in 1970 under a time-limit, he became Lecturer, and later Senior Lecturer, in Zoology at University College, Cardiff, where he was in charge of genetics.

Unlike many scientists and scholars in general, Robert Creed did not find his period of National Service a disastrous waste of time. Among other things, it enabled him to develop his ability in engineering. Indeed, he retained what to some of us seemed an astonishing capacity to interchange and adjust the parts of old motor cars, of which he always had several. Moreover, for the rest of his life he took an active interest in the Territorial Army Volunteer Reserve.

His marriage to Elizabeth Hilton was a source of great happiness. He leaves two daughters, one aged 7 and the other 4 years. He liked to live in fairly large houses plentifully supplied with cats.

He was a good lecturer, but his outstanding educational achievement was as a demonstrator in practical classes. Here he excelled. He would take great care to arrange interesting exhibits and experiments. It was his habit to take away and work up the class results, and he would subsequently explain in what ways they had proved rewarding or unusual.
He was also a successful research worker. In order to investigate the ecological genetics of the butterfly Maniola jurtina he once camped with me on an uninhabited island in the Isles of Scilly, and he repeatedly joined our research group studying that insect in the south-west of England. He had a flair for such work, in which his observations were accurate and often revealing; and on these occasions his light-hearted energy was an asset and an encouragement.

His own researches were in particular directed to the polymorphism of the two-spot ladybeetle, Adalia bipunctata. This is typically scarlet with a black spot on each wing-cover; but two black forms with, respectively, four and six red spots are also known, all three types being controlled as multiple alleles. Creed showed that the black phases are industrial melanics, the only known instance of that condition in a species protected from predation by a powerfully unpleasant scent and taste: one practising, therefore, the aposematic way of life.

Creed and his colleagues also found that the black phases of $A$. bipunctata are favoured when pollution results from coal of high volatility, not of low volatility as in South Wales; nor does the presence of sulphur dioxide in the atmosphere encourage their spread, as in some moths. Moreover, the two black forms respectively survive better when the fuel is, or is not, subject strongly to caking. This work, described in his published articles, is a valuable contribution to our knowledge of adaptation to industrial conditions.

In spite of his youthful appearance, Robert Creed had a highly developed critical faculty and his comments when the draft of an article was submitted to him were of penetrating value. He was a Conservative in politics, original in research, devoted in friendship. His early death is a tragic loss of one who can ill be spared.

E. B. Ford

\section{Lord Cranbrook}

ThE death of John David, 4th Earl of Cranbrook on 22 November 1978 deprives many natural history and scientific societies of a skilful adviser and an enthusiastic and knowledgeable colleague.

His multifarious activities in public service and in support of East Anglian naturalists' organisations have been acclaimed elsewhere (The Times, 24 November 1978) but it is for his capacities as a scientist of no mean distinction and as a staunch member and officer of national biological societies that we, on behalf of the 